\title{
Kajian Paket Dosis Semi Organik terhadap Sifat Tanah dan Hasil Tanaman Padi (Oryza sativa L)
}

\author{
I WAYAN NARKA*), I NYOMAN DIBIA, DAN I WAYAN DANA ATMAJA \\ Program Studi Agroekoteknologi Fakultas Pertanian Universitas Udayana \\ Jl. P.B. Sudirman, Denpasar, Bali 80232 \\ ${ }^{*}$ E-mail: wayannarka@gmail.com
}

\begin{abstract}
The study of packages of semi-organic fertilization on soil properties, and yield of rice (Oryza sativa $\mathbf{L}$ ). The aim of this study was to know the effect of semi organic fertilization doses on soil properties and yield of rice. The Randomized block design (RBD), with 3 replications and 9 treatments was used in this study. P0 (without fertilizer), P1 (25 tons of organic fertilizer ha-1), P2 (300 kg of Urea ha-1, $150 \mathrm{~kg} \mathrm{SP} 36$ ha- 1 and $75 \mathrm{~kg} \mathrm{KCl}$ ha-1), P3 (biourin liquid fertilizer) P4 (1/2 P1 + 1/2 P2), P5 (1/2 P1 + 1/2 P3, P6 (1/2 P2 + 1/2 P3), P7 $(2 / 3 \mathrm{P} 1+1 / 3 \mathrm{P} 2)$ and $\mathrm{P} 8(2 / 3 \mathrm{P} 3+1 / 3 \mathrm{P} 2)$. The results showed that the application of semiorganic fertilizer on soil properties such as soil salinity, C-organic content, P-available and Nitrogen content of soil significantly affected by the treatment, while potasium_available and soil $\mathrm{pH}$ is not significantly affected by the treatment. Yield of rice had a very significant effected by treatment. The semi-organic fertilizer P4 (combination of 50\% anorganic $+50 \%$ organic compost) and P6 (combination of $50 \%$ inorganic $+50 \%$ biourine) can produce oven dry grain $33.35 \mathrm{~g}$ per bushel and $32.63 \mathrm{~g}$ per bushel respectively or increased $57.91 \%$ and $54.50 \%$ of controls.
\end{abstract}

Keywords: semi organic fertilizers, organic fertilizer, anorganic fertilizer, rice

\section{PENDAHULUAN}

Usahatani semi organik menerapkan inovasi pengurangan pemakaian pupuk kimia dan mensubtitusikannya dengan menggunakan pupuk organik, serta membebaskan lahan usahatani dari pemakaian pestisida kimia. Penggunaan pupuk kimia secara terus-menerus tanpa diimbangi oleh pupuk organik dapat menyebabkan kesuburan tanah semakin rendah. Hasil penelitian tentang pemberian pupuk organik dan pupuk kimia yang dilakukan di Baturiti Tabanan menunjukkan bahwa pemberian pupuk kimia selama 5 tahun tanpa disertai pupuk organik dapat menurunkan kualitas tanah (Sardiana, 2015). 


\section{WAYAN NARKA. et al. Kajian Paket Dosis Semi Organik terhadap Sifat Tanah...}

Penggunaan pupuk organik digalakkan kembali sekarang (back to nature), tetapi pemberian pupuk organik tanpa diikuti dengan pupuk kimia ternyata menurunkan hasil secara drastis pada tahun pertama saat pemberian. Hal ini disebabkan karena tidak ada pupuk organik yang memiliki kandungan hara tinggi atau setara pupuk kimia. Hasil penelitian penggunaan pupuk organik kascing di daerah Baturiti Tabanan menunjukkan bahwa pada tahun pertama pemberian pupuk organik, hasil sayuran menurun sekitar $48 \%$ (Sardiana, 2015). Mencegah terjadinya penurunan hasil sayuran, pupuk organik dikombinasikan dengan pupuk kimia. Penggunaan kombinasi pupuk organik dengan pupuk kimia sering disebut dengan pertanian semi organik.

Pertanian semi organik merupakan suatu bentuk tata cara pengelolaan tanah dan budi daya tanaman dengan memanfaatkan pupuk yang berasal dari bahan organik dan pupuk kimia untuk meningkatkan kandungan hara yang dimiliki oleh pupuk organik. Pertanian semi organik bisa dikatakan pertanian yang ramah lingkungan, karena dapat mengurangi pemakaian pupuk kimia sampai di atas $50 \%$. Pada masa mendatang diharapkan penggunaan pupuk kimia ini dapat dilepaskan seutuhnya.
Ketua Ikatan Petani Organik

Gunungkidul Iswanto (dalam harianjogja 2015) mengatakan, petani belum bisa meninggalkan pupuk kimia. Penggunaan pupuk kimia akan dikurangi secara perlahan dan digantikan dengan pupuk organik. Model pertanian yang dikembangkan masih semi organik, karena masih menggunakan sebagian pupuk kimia untuk pemeliharaan. Namun demikian, panen yang dihasilkan dapat maksimal karena per hektar mampu menghasilkan 12 ton gabah (http://www.harianjogja.com).

Dalam pertanian semi organik, pupuk organik yang digunakan bisa berupa pupuk organik cair, pupuk organik padat seperti pupuk kompos, pupuk kandang atau pupuk hijau. Demikian juga persentase pupuk organik bervariasi.

\section{BAHAN DAN METODE}

Penelitian ini dilakukan di rumah kaca kebun percobaan Fakultas Pertanian Universitas Udayana. Masing-masing pot diisi dengan $10 \mathrm{~kg}$ tanah, kemudian diberikan perlakuan paket dosis pupuk semi organik. Rancangan yang digunakan pada percobaan ini adalah rancangan acak kelompok (RAK) dengan 3 ulangan dan 9 perlakuan paket dosis pemupukan. Adapun paket dosis yang diteliti adalah: P0 (tanpa pupuk), P1 (25 ton 
pupuk organik kompos/ha), P2 (300 kg pupuk Urea/ha, $150 \mathrm{~kg}$ SP36/ha dan $75 \mathrm{~kg}$ KCL/ha), P3 (pupuk cair biourin), P4 (1/2 $\mathrm{P} 1+1 / 2 \mathrm{P} 2), \mathrm{P} 5(1 / 2 \mathrm{P} 1+1 / 2 \mathrm{P} 3), \mathrm{P} 6(1 / 2 \mathrm{P} 2+1 / 2$ $\mathrm{P} 3), \quad \mathrm{P} 7(2 / 3 \mathrm{P} 1+1 / 3 \mathrm{P} 2)$ dan $\mathrm{P} 8(2 / 3 \mathrm{P} 3+$ 1/3P2).

Selain paket semi organik juga ada perlakuan tanpa pupuk (P0) sebagai control dan pemupukan anorganik NPK (P2) sebagai acuan dalam menentukan Relative Agronomic Effectiveness (RAE). Parameter yang dia. mati meliputi parameter tanah dan tanaman. Parameter tanah meliputi: kadar nitrogen $(\mathrm{N})$, fosfor $(\mathrm{P})$, kalium $(\mathrm{K}), \mathrm{pH}$ tanah, C-organik, dan kadar garam (salinitas) tanah, sedangkan parameter hasil tanaman adalah berat gabah kering oven.

Metode analisis tanah yang digunakan adalah: penetapan kadar $\mathrm{N}$ tanah dengan metode Kjeldahl, $\mathrm{P}$ dan $\mathrm{K}$ dengan metode Bray 1, C-organik dengan metode Walkey \& Black, dan kadar garam dengan metode electric conductometer. Bahan yang digunakan dalam penelitian ini adalah: tanah, bibit padi IR64, zat-zat kimia untuk analisis tanah, pupuk organik kompos, pupuk cair biourin kencing sapi, dan pupuk kimia (anorganik). Sedangkan alat-alat yang digunakan adalah: ember untuk pot penanaman, ayakan tanah, alat penyiraman, sprayer untuk menyemprotkan larutan pupuk cair biourin, oven, timbangan, dan alat-alat lain untuk analisis tanah.

\section{HASIL DAN PEMBAHASAN}

Pengaruh pemberian beberapa paket dosis pemupukan semi organik tidak berpengaruh nyata terhadap $\mathrm{pH}$ tanah. Hal ini mungkin disebabkan karena pengamatan $\mathrm{pH}$ tanah dilakukan pada saat panen (15 minggu setelah tanam). Agustin dan Suntari (2018) melaporkan pemberian pupuk kompos dan Urea pada 12 minggu setelah masa inkubasi tidak berpengaruh nyata terhadap $\mathrm{pH}$ tanah namun pada 8 minggu setelah inkubasi berpengaruh nyata.

Salinitas tanah (kadar garam) menunjukkan perbedaan nyata akibat perlakuan yang diberikan (Tabel 1). Kisaran nilai nilai salinitas tanah masih dalam satu kretiria yaitu "sangat rendah" sehingga tidak menggangu pertumbuhan tanaman padi. Perbedaan nilai salinitas tanah disebabkan karena pupuk anorganik berupa garam garam dapat meningkatkan daya hantar listrik atau salinitas tanah. Demikian juga pupuk organik setelah mengalami proses dekomposisi dapat menghasilkan asam humat, asam vulfat yang tergolong asam lemah dapat meningkatkan daya hantar listrik tanah.

Pengaruh pemberian beberapa paket dosis pupuk secara statistic berpengaruh 


\section{WAYAN NARKA. et al. Kajian Paket Dosis Semi Organik terhadap Sifat Tanah...}

sangat nyata terhadap kandungan C-organik tanah dan berpengaruh nyata terhadap kadar $\mathrm{P}$ tersedia. Meningkatnya kandungan Corganik tanah disebabkan karena pupuk kompos yang diberikan mengandung $\mathrm{C}$ organik sebesar 20,14\%. Sejalan dengan hasil penelitian ini, Hanum dkk. (2016) melaporkan pemberian bahan organik dan pupuk anorganik dapat meningkatkan kadar C organik tanah dan kapasitas tukar kation. Peningkatan kandungan bahan organik dalam tanah akan dapat meningkatkan asam organik yang bersifat asam lemah yang selanjutnya dapat meningkatkan kelarutan Phosfor.
Berdasarkan hasil analisis tanah kandungan P-tersedia juga menunjukkan kecenderungan meningkat pada pemberian pupuk organik (Tabel 1). Nuro et.al. (2016) melaporkan bahwa pupuk organik kompos dapat memperbaiki sifat kimia tanah dan dapat meningkatkan produksi kangkung darat. Demikian juga Adijaya dan Yasa (2014) melaporkan pemberian pupuk organik pada lahan kering Gerokgak dapat memperbaiki sifat tanah seperti berat volume tanah mengalami penurunan, kadar air, porositas total dan kadar $\mathrm{C}$ organik tanah serta kadar $\mathrm{N}$ total mengalami kenaikan.

Tabel 1. Pengaruh pemberian paket dosis pemupukan semi organik terhadap beberapa sifat tanah

\begin{tabular}{lcccccc}
\hline $\begin{array}{l}\text { Perlakuan/ } \\
\text { Pengamatan }\end{array}$ & $\begin{array}{c}\mathrm{pH} \\
\text { tanah }\end{array}$ & $\begin{array}{c}\text { C-organik } \\
\text { tanah }(\%)\end{array}$ & $\begin{array}{c}\mathrm{N} \text { tanah } \\
(\%)\end{array}$ & $\begin{array}{c}\text { P tersedia } \\
(\mathrm{ppm})\end{array}$ & $\begin{array}{c}\text { K tanah } \\
(\mathrm{ppm})\end{array}$ & $\begin{array}{c}\text { Salinitas } \\
(\mu \text { mhos } \\
\left./ \mathrm{cm}^{2}\right)\end{array}$ \\
\hline P0 (tanpa pupuk), & $6.8 \mathrm{a}$ & $2.60 \mathrm{a}$ & $0.14 \mathrm{a}$ & $2.84 \mathrm{a}$ & $68.33 \mathrm{a}$ & $91.7 \mathrm{a}$ \\
P1 (Organik) & $6.6 \mathrm{a}$ & $3.55 \mathrm{~b}$ & $0.19 \mathrm{ab}$ & $10.12 \mathrm{cde}$ & $95.00 \mathrm{a}$ & $136.3 \mathrm{ef}$ \\
P2 (Anorganik) & $6.7 \mathrm{a}$ & $2.50 \mathrm{a}$ & $0.30 \mathrm{c}$ & $15.31 \mathrm{f}$ & $105.58 \mathrm{a}$ & $139.7 \mathrm{f}$ \\
P3 ((biourin)) & $6.8 \mathrm{a}$ & $2.47 \mathrm{a}$ & $0.15 \mathrm{a}$ & $5.42 \mathrm{ab}$ & $67.33 \mathrm{a}$ & $116.7 \mathrm{~cd}$ \\
P4 (1/2 P1+1/2 P2) & $6.7 \mathrm{a}$ & $3.51 \mathrm{~b}$ & $0.28 \mathrm{bc}$ & $12.38 \mathrm{de}$ & $102.67 \mathrm{a}$ & $134.3 \mathrm{def}$ \\
P5 (1/2 P1+1/2 P3) & $6.7 \mathrm{a}$ & $3.29 \mathrm{~b}$ & $0.20 \mathrm{abc}$ & $8.13 \mathrm{bc}$ & $81.67 \mathrm{a}$ & $110.7 \mathrm{bc}$ \\
P6 (1/2 P2 +1/2 P3) & $6.7 \mathrm{a}$ & $2.45 \mathrm{a}$ & $0.24 \mathrm{abc}$ & $9.52 \mathrm{cde}$ & $84.33 \mathrm{a}$ & $128.0 \mathrm{cde}$ \\
P7 (2/3P1+1/3P2) & $6.7 \mathrm{a}$ & $3.43 \mathrm{~b}$ & $0.29 \mathrm{c}$ & $11.05 \mathrm{cde}$ & $95.33 \mathrm{a}$ & $135.0 \mathrm{def}$ \\
P8 (2/3P3+1/3P2) & $6.8 \mathrm{a}$ & $2.71 \mathrm{a}$ & $0.20 \mathrm{abc}$ & $8.90 \mathrm{bcd}$ & $86.53 \mathrm{a}$ & $117.3 \mathrm{cde}$ \\
\hline
\end{tabular}

Keterangan : Angka-angka yang diikuti oleh huruf yang sama pada kolom yang sama tidak berbeda nyata pada uji Duncant $5 \%$ 
Berdasarkan hasil analisis statistika hasil yang diberikan dengan adanya terlihat bahwa pemberian perlakuan paket pemupukan semi organic cukup tinggi dan pupuk semi organik berpengaruh sangat tidak berbeda nyata dengan pemupukan nyata terhadap berat gabah kering oven. anorganik (P2). Hasil gabah kering oven Hasil gabah per rumpun tertinggi pada mengalami penurunan secara tidak nyata perlakuan pemberian paket pemupukan dibandingkan dengan paket anorganik (P2), anorganik (P2) yaitu sebesar 36,63 gram per tetapi sifat tanah mengalami perbaikan. Oleh rumpun. Kemudian diikuti oleh paket dosis P4 ( $1 / 2$ pupuk organik $+1 / 2$ pupuk anorganik) dan paket dosis P6 (1/2 pupuk anorganik + 1/2 pupuk cair biourin) masing-masing 33,35 g dan $32,63 \mathrm{~g}$ per rumpun, atau mengalami peningkatan masing-masing $57,91 \%$ dan $54,46 \%$ terhadap control dan secara statistic antara P2, P4 dan P6 tidak berbeda nyata (Tabel 2). Meningkatnya hasil gabah dibandingkan dengan control disebabkan karena beberapa sifat tanah mengalami perbaikan seperti meningkatnya kadar $\mathrm{N}$ total, $\mathrm{P}$ tersedia dan kadar $\mathrm{C}$ organik tanah (Tabel 1). Senada dengan hasil penelitian Minardi dkk. (2009) melaporkan perimbangan pupuk organik dan pupuk anorganik berpengaruh nyata terhadap sifat kimia tanah seperti $\mathrm{N}$ total, $\mathrm{N}$ tersedia dan Kapasitas Tukar Kation Tanah serta hasil wortel.

Hasil gabah kering oven pada pemupukan semi organik ini (P4 dan P6) tidak mencapai hasil gabah kering oven sebesar pemupukan anorganik (P2), tetapi karena itu, dalam jangka panjang diharapkan dapat memperbaiki kualitas tanah. Swandewi, (2017). meneliti pemberian pupuk organik cair dikombinasikan dengan pupuk organik padat (kompos) dan pupuk anorganik (pupuk NPK) di Subak Mambal, Penebel, Tabanan pada tiga lokasi (munduk) memperoleh hasil yang sangat menggembirakan. Pemberian dosis 1 ton pupuk organik/ha +135 pupuk phonska/ha +15 kg pupuk Mutiara/ha +50 liter biourin konsentrasi $5 \%$ dilakukan pada Munduk Kedampal, Bedugul dan Semana masingmasing menghasilkan gabah kering panen sebesar 6,56 ton/ha, 7,8 ton/ha, dan 7,5 ton/ha, sementara pemberian pupuk anorganik saja menghasilkan masing-masing 5,76 ton/ha, 5,72 ton/ha dan 6,4 ton/ha.

Pemberian pupuk cair biourine (P3) menghasilkan gabah kering oven 25,47 g per rumpun atau mengalami kenaikan sebesar $20,60 \%$ terhadap control dan tidak berbeda nyata dengan kontrol (Table 2). Rendahnya peningkatan berat gabah kering oven pada 


\section{WAYAN NARKA. et al. Kajian Paket Dosis Semi Organik terhadap Sifat Tanah...}

perlakuan pemberian biourin kencing sapi (P3) dibandingkan dengan paket yang lainnya mungkin disebabkan karena dosis yang digunakan 2 cc/liter air belum optimal. Supartha Dkk. (2012) melaporkan penambahan pupuk cair Budd Terra dan pupuk cair Solbi Agro pada tanaman padi dapat meningkatkan hasil gabah kering panen antara 4,4 sampai $17,4 \%$ dibandingkan dengan kontrol. Selanjutnya peneliti lain Marliah dkk. (2012) juga melaporkan bahwa, dosis terbaik pemberian pupuk cair Enviro Plus adalah 0,5 cc/liter air dan dapat meningkatkan pertumbuhan dan hasil tomat. Peningkatan hasil tanaman akibat penggunaan pupuk cair bervariasi tergantung jenis pupuk cair dan dosis yang digunakan. Selain disebabkan oleh dosis yang belum optimal, mungkin juga disebabkan karena menggunakan satu jenis pupuk saja, tidak melibatkan pupuk organik atau pupuk anorganik. Penggunaan lebih dari satu jenis pupuk seperti pada Paket P6 dapat meningkatkan hasil gabah kering oven.

Perlakuan P1 (pemberian pupuk organik 25 ton/ha) menunjukkan respon yang lebih baik jika dibandingkan perlakuan P0 (control) pada hasil tanaman padi. Peningkatan hasil gabah kering oven sebesar $14,96 \%$ dibandingkan dengan control (Tabel 2). Peningkatan ini disebabkan karena pupuk organik mengandung hara $\mathrm{N}, \mathrm{P}, \mathrm{K}$ sehingga unsur hara dalam tanah menjadi lebih tersedia. Kandungan pupuk kompos yang dipakai pada penelitian ini: unsur nitrogen $0,86 \%, \mathrm{P}_{2} \mathrm{O}_{5} 2,10 \% ; \mathrm{K}_{2} \mathrm{O} 1,40 \%$, sehingga tambahan unsur N, P, K adalah sebesar 4,36 $\%$. Senada dengan hasil penelitian ini, Adijaya dan Yasa (2014) melaporkan bahwa pemberian pupuk organik berpengaruh terhadap sifat tanah, pertumbuhan dan hasil tanaman jagung. Peneliti sebelumnya Agustina (2007) melakukan penelitian pengaruh pemberian kompos terhadap beberapa sifat fisik tanah Entisol serta pertumbuhan tanaman jagung (Zea mays L). Hasil penelitian menunjukkan bahwa pemberian kompos dapat memperbaiki sifat tanah Entisol dan meningkatkan pertumbuhan jagung. Pemberian kompos dengan dosis 30 ton/ha berpengaruh terbaik dalam memperbaiki beberapa sifat fisik tanah. Luthfyrakhman dan Susila (2013) meneliti optimasi dosis pupuk anorganik dan pupuk kandang ayam pada budidaya tomat hibrida menemukan bahwa dosis optimum pupuk kandang ayam 24,375 ton/ha.

Perlakuan P4 (kombinasi 50\% anorganik $+50 \%$ organic kompos) berpengaruh nyata terhadap berat gabah kering oven. Berat gabah kering oven mengalami peningkatan secara nyata sebesar 
57,91\%. Peningkatan ini disebabkan karena ketersediaan unsur hara dalam tanah dan pemberian kombinasi pupuk anorganik NPK pupuk organik juga memberikan tambahan dengan pupuk organik kompos. Pupuk hara serta perbaikan sifat tanah. Masinganorganik secara langsung dalam jumlah masing pupuk dapat menambah ketersediaan yang relatif besar dapat menambah hara.

Tabel 2. Pengaruh pemberian beberapa paket dosis pemupukan semi organik terhadap hasil gabah kering oven, RAE dan persentase peningkatannya terhadap control

\begin{tabular}{lccc}
\hline $\begin{array}{l}\text { Perlakuan/ } \\
\text { Pengamatan }\end{array}$ & $\begin{array}{l}\text { Berat } \\
\text { oven per rumpun }(\mathrm{g})\end{array}$ & $\begin{array}{c}\text { Relative Agronomyc } \\
\text { Effectiveness }(\%)\end{array}$ & $\begin{array}{c}\text { Persentase } \\
\text { Peningkatan GKP } \\
(\%)\end{array}$ \\
\hline P0 (tanpa pupuk), & $21.12 \mathrm{a}$ & - & - \\
P1 (Organic) & $24.28 \mathrm{a}$ & 20.39 & 14.96 \\
P2 (Anorganik) & $36.63 \mathrm{~b}$ & 100.00 & 73.44 \\
P3 ((biourin)) & $25.47 \mathrm{a}$ & 28.06 & 20.60 \\
P4 (1/2 P1+1/2 P2) & $33.35 \mathrm{~b}$ & 78.90 & 57.91 \\
P5 (1/2 P1 + 1/2 P3) & $27.90 \mathrm{a}$ & 43.74 & 32.10 \\
P6 (1/2 P2 + 1/2 P3) & $32.63 \mathrm{~b}$ & 74.26 & 54.50 \\
P7 (2/3P1 + 1/3P2) & $28.47 \mathrm{a}$ & 47.42 & 34.80 \\
P8 (2/3P3 + 1/3P2) & $31.52 \mathrm{~b}$ & 66.97 & 49.15 \\
\hline
\end{tabular}

Perlakuan P5 (kombinasi $(1 / 2$ P1 + 1/2 P3) dapat meningkatkan gabah kering oven sebesar 32,10\% dibandingkan control dan secara statistic tidak menunjukkan perbedaan yang nyata. Demikian juga paket P7 (2/3P1 + 1/3P2) dapat meningkatkan hasil gabah kering oven sebesar 34,80\% terhadap control dan secara statistic tidak nyata (Tabel 2). Persentase peningkatannya jauh lebih besar dibandingkan dengan paket $100 \%$ pupuk organik (P1) ataupun paket 100\% Biourin kencing sapi (P3). Hal ini menunjukkan bahwa peranan pupuk anorganik sangat penting dalam meningkatkan pertumbuhan dan hasil tanaman. Apabila pupuk anorganik dikurangi, walupun pupuk organik ditingkatkan menjadi 2/3 P1 pada paket P7, peningkatan hasil gabah kering oven ditemukan relative rendah. Pupuk organik memang dapat meningkatkan hasil tanaman padi, namun peningkatannya relatif kecil dibandingkan pupuk anorganik NPK. Kecilnya peningkatan hasil disebabkan karena hara yang terkandung pada pupuk organik, baik yang padat maupun yang cair 


\section{WAYAN NARKA. et al. Kajian Paket Dosis Semi Organik terhadap Sifat Tanah...}

sangat rendah bila dibandingkan dengan pupuk anorganik NPK.

Perlakuan P6 (kombinasi pupuk 50\% pupuk anorganik $+50 \%$ pupuk cair biourin) secara nyata menunjukkan peningkatan hasil gabah kering oven. Peningkatan hasil gabah kering oven sebesar 54,46 \% jika dibandingkan dengan control (P0), Peningkatan ini disebabkan karena pupuk anorganik yang diberikan dapat menyediakan unsur hara bagi tanaman padi, demikian juga pupuk biourine mengandung hara yang dibutuhkan tanaman. Balai Pengkajian Teknologi Pertanian Kepulauan Bangka Belitung (2018) melaporkan kandungan hara pupuk biourin kencing sapi adalah sebagai berikut: C organik 21,29 \%, N 1,67 \%, P 2,59 $\%, \mathrm{~K} 22,50 \%, \mathrm{Na} 6,27 \%, \mathrm{Ca} 0,47 \%, \mathrm{Mg}$ $1,80 \%$ dengan $\mathrm{C} / \mathrm{N}$ ratio 12,75 . Jika perlakuan P3 (biourine), dibandingkan dengan perlakuan P6, Perlakuan P6 menghasilkan hasil gabah jauh lebih tinggi dan secara statistic berbeda nyata (Tabel 2). Hal ini menunjukkan peranan pupuk anorganik sangat penting dalam meningkatkan pertumbuhan dan hasil tanaman. Puspadewi dkk. (2016) menemukan bahwa kombinasi pemberian konsentrasi pupuk organik cair $2 \mathrm{ml} /$ liter air dan $1 / 2$ dosis NPK memberikan pengaruh yang lebih baik terhadap pertumbuhan dan hasil tanaman jagung manis.

\section{Perlakuan P2 (pemberian pupuk} anorganik) berpengaruh nyata terhadap berat gabah kering oven per rumpun. Pemberian $300 \mathrm{~kg}$ pupuk Urea/ha, $150 \mathrm{~kg} \mathrm{SP36/ha} \mathrm{dan}$ $75 \mathrm{~kg} \mathrm{KCL} / \mathrm{ha}$ (P2), dapat meningkatkan hasil tanaman padi (gabah kering oven) sebesar sebesar 73,44 \% dibandingkan dengan control, yang secara statistic berbeda nyata dengan perlakuan P0, P1 dan P3 (Tabel 2). Peningkatan ini jauh lebih besar dibandingkan dengan perlakuan pemberian pupuk organik. Hal ini disebabkan kandungan hara pada pupuk anorganik jauh lebih tinggi dan cepat tersedia dibandingkan dengan pupuk organik. Kandungan hara yang lebih tinggi akan menyebabkan ketersediaan hara yang lebih tinggi di tanah, selanjutnya akan berpengaruh terhadap pertumbuhan dan hasil tanaman padi. Berdasarkan hasil gabah kering oven yang diperoleh pada beberapa paket semi organik (P4, P6, P7 dan P8) terlihat bahwa pupuk anorganik sangat menentukan hasil tanaman padi karena pupuk anorganik kandungan haranya tinggi dan mudah tersedia bagi tanaman

$$
\text { RAE (Relatif Agronomic }
$$

Effectiveness) pemupukan semi organik, merupakan perbandingan selisih hasil 
tanaman antara perlakuan pemberian pupuk semi organik dengan control dibandingkan dengan selisih hasil tanaman antara pemupukan konvensional (pupuk anorganik) dengan control. RAE pemupukan semi organik semuanya dibawah $100 \%$. Hal ini berarti hasil gabah kering oven yang diperoleh pada paket semi organik lebih rendah dari paket acuan yaitu pupuk anorganik NPK). Nilai RAE yang cukup tinggi adalah pada perlakuan P4 (50 \% organik kompos dan 50\% anorganik) yaitu sebesar 78,90\% dan pada perlakuan P6 (50 \% organik biourine dan $50 \%$ anorganik) yaitu sebesar 74,26\%. Kedua paket semi organik ini dapat disarankan karena hasil gabah kering oven secara statistic tidak berbeda nyata. Hasil gabah kering oven pada paket P4 dan P6 lebih rendah dan tidak berbeda nyata dibandingkan dengan paket anorganik (P2), sehingga dapat disarankan untuk menjaga dan menaikkan kualitas tanah.

\section{SIMPULAN}

Berdasarkan hasil analisis statistic dan hasil pembahasan, dapat disimpulkan beberapa hal sebagai yaitu pemupukan semi organik berpengaruh nyata terhadap beberapa sifat tanah seperti: kadar C-organik tanah, kadar P-tersedia, kadar nitrogen tanah dan salinitas tanah, sedangkan terhadap $\mathrm{pH}$ tanah dan kadar kalium tanah tidak nyata. Pemberian paket dosis pemupukan semi organik P4 dan P6 serta P8 berpengaruh sangat nyata terhadap hasil tanaman padi. Paket pemupukan semi organik P4 (kombinasi $50 \%$ anorganik $+50 \%$ organik kompos) dapat menghasilkan gabah kering oven $33,35 \mathrm{~g}$ per rumpun atau meningkat sebesar 57,91 \% terhadap kontrol. Paket pemupukan semi organik P6 (kombinasi 50\% anorganik $+50 \%$ biourine) menghasilkan gabah kering oven $32,63 \mathrm{~g}$ per rumpun atau meningkat sebesar $54,50 \%$ dibandingkan control. Relatif Agronomic Effectiveness (RAE) pada perlakuan semi organik tidak dapat melebihi $100 \%$. Nilai RAE paket P4 dan P6 masing- masing 78,90\% dan 74,26\%.

\section{UCAPAN TERIMA KASIH}

Penulis mengucapkan terima kasih kepada Lembaga Penelitian dan Pengabdian kepada Masyarakat (LPPM) dan Dekan Fakultas Pertanian Universitas Udayana atas dukungan dana yang telah diberikan sehingga kegiatan penelitian ini dapat dilaksanakan

\section{DAFTAR PUSTAKA}

Adijaya, I. N., dan I. M. R. Yasa. (2014). Pengaruh Pupuk Organik terhadap Sifat Tanah, Pertumbuhan dan Hasil Jagung. Prosiding Seminar Nasional " Inovasi Teknologi Pertanian Spesifik Lokasi “. 
I WAYAN NARKA. et al. Kajian Paket Dosis Semi Organik terhadap Sifat Tanah...

Banjarbaru 6-7 Agustus 2014. Hal. 299-310

Agustina, C. (2007). Pengaruh Pemberian Kompos terhadap Beberapa Sifat Fisik Entisol serta Pertumbuhan Tanaman Jagung (Zea mays L). Skripsi. Fakultas Pertanian Universitas Brawidjaya. Malang.

Agustin, S.E. dan R. Suntari. (2018). Pengaruh Aplikasi Urea dan Kompos terhadap Sifat Kimia Tanah serta Pertumbuhan Jagung (Zea mayz L.) pada Tanah Terdampak Erupsi Gunung Kelud. Jurnal Tanah dan Sumberdaya Lahan Vol. 5 No. 1 : 775-783

Balai Pengkajian Teknologi Pertanian Kepulauan Bangka Belitung. (2018). Pembuatan Bio Urine Berbahan Baku Urine Ternak Sapi. Http:// babel.litbang.pertanian.go.id $>$ sdm-2

Minardi, S., J. Winarno, A. H. N. Abdilah. (2009). Efek Perimbangan Pupuk Organik dan Anorganik terhadap Sifat Kimia Tanah Andisol Tawangmangu dan Hasil Tanaman Wortel (Daucus carota L.). Sains Tanah - Jurnal Ilmu Tanah dan Agroklimatologi 6 (2) : 111116

Nuro, F., D. Priadi, E.S. Mulyaningsih. (2012). Efek Pupuk Organik terhadap Sifat Kimia Tanah dan Produksi Kangkung Darat (Ipomoea reptans Poir). Prosiding Seminar Nasional Hasil-Hasil PPM IPB 2016. Hal. 2939

El- Nagar, A.H. (2010). Effect Biofertilzer, organik compost and mineral fertilizers on the growth, flowering and bulbs production of Narcissus tazetta L. $J$. Agric,\&env. Sci.Alex. Univ., Egipt. Vol .9 (1) 2010.

Hanum, H, H. Guchi, dan Jamilah. (2016). Pengaruh Pemberian Pupuk Anorganik dan Organik terhadap Sifat Kimia Tanah di Lahan Sawah dengan Sistem Tanam SRI dan Konvensional.
Prosiding Seminar Nasional Lahan Suboptimal 2016, Palembang, 20-21 Oktober 2016. Hal. 267- 273

http://www.harianjogja.com/baca/2015/03/17 /pupuk-organik-belum-tinggalkanpupuk-kimia-seperti-ini-penggunaanpupuk-semi-organik-585507

Luthfyrakhman. H. , A. D. Susila. (2013). Optimasi Dosis Pupuk Anorganik dan Pupuk Kandang Ayam pada Budidaya Tomat Hibrida (Lycopersicon esculentum Mill. L.) Bul. Agrohorti 1 (1) : 119 - 126. Departemen Agronomi dan Hortikultura, Fakultas Pertanian, Institut Pertanian Bogor

Marliah, A., M. Hayati, I. Muliansyah. (2012). Pemanfaatan Pupuk Organik Cair terhadap Pertumbuhan dan Hasil Beberapa Varietas Tomat (Lycopersicum esculentum L.). Jurnal Agrista No. 16 Vol. 3 : 122-128. Program Studi Agroekoteknologi Fakultas Pertanian Universitas Syiah Kuala, Banda Aceh.

Puspadewi, S., W. Sutari, Kusumiyati. (2016). Pengaruh Konsentrasi Pupuk Organik Cair (POC) dan Dosis Pupuk $\mathrm{N}, \mathrm{P}, \mathrm{K}$ terhadap Pertumbuhan dan Hasil Jagung Manis (Zea mays L. var Rugosa Bonaf). Jurnal Kultivasi Vol. (15 (3) : 208-216. Desember 2016

Sardiana, I K. (2015). Simpanan Karbon Organik, Kualitas Tanah, dan Hasil Caisin (Brassica chinensis) pada Pertanian Organik dan Konvensional di Kecamatan Baturiti, Kabupaten Tabanan, Bali. Disertasi Doktor. Program Pasca Sarjana Universitas Udayana Denpasar.

Supartha, I.N.Y., G. Wijana, G. M. Adnyana. (2012). Aplikasi Jenis Pupuk Organik pada Tanaman Padi Sistem Pertanian Organik. E-Jurnal Agroekoteknologi Tropika Vol. 1 No. 2 : 98-106 